\title{
Maintenance and Personal Safety in Neighborhood Parks: A literature and case study of MPSJ
}

\author{
Nurfadilah Saadul Kurzi, Olaf Schroth \\ Department of Landscape, \\ The University of Sheffield, Arts Tower, Western Bank, Sheffield, UK \\ nbsaadulkurzi1@sheffield.ac.uk
}

\begin{abstract}
This paper discusses the maintenance and procedure in Subang Jaya City Council (MPSJ), and on the effect on the perception of safety. Eight $(n=8)$ experts interviews and observations in three neighborhood parks were conducted. The findings emphasize that maintenance has significantly influenced perceived safety, and different environments have different impacts depending on context, topography, planting, and level of privacy. The location of neighborhood park (NP) 1 in a middle of housing areas and a university caters three end-users: residents, academic staffs, and students. The distinctive character of natural planting in NP3 created a different environment unlike NP2, where the planting is rather formal. Thus has considerably significant and laid different level of perceived safety.
\end{abstract}

Keywords: Maintenance practice; perceived safety; expert interviews; urban parks and green spaces

eISSN 2398-4279 @ 2018. The Authors. Published for AMER ABRA cE-Bs by e-International Publishing House, Ltd., UK. This is an open access article under the CC BY-NC-ND license (http://creativecommons.org/licenses/bync-nd/4.0/). Peer-review under responsibility of AMER (Association of Malaysian Environment-Behaviour Researchers), ABRA (Association of Behavioural Researchers on Asians) and CE-Bs (Centre for EnvironmentBehaviour Studies), Faculty of Architecture, Planning \& Surveying, Universiti Teknologi MARA, Malaysia.

DOI: https://doi.org/10.21834/ajqol.v3i13.167 


\subsection{Introduction}

Studies on the perception of personal safety have made some assertions on what may, and what may not, influence individual's perception of their physical environment. Even though the findings of these studies concentrate on more tangible objects, such as physical factors, and intangible factors, such as experience and demographic, most of the resultant discussion and recommendations focus on maintenance factors and the importance of their improvement.

The understanding of the landscape itself as described by Hussein (2014) as a "phenomenon that evolves continuously through time and space" through experience. Bacon (1976), discussed the influence of experience in imposes emotions on users in either a positive or negative manner (Sreetheran \& van den Bosch, 2014), and consequently affects their activities in the park (Kashef, 2008; Kaplan \& Kaplan, 1989). Safety and comfort are both key determinants of the utilization of public spaces (Dempsey and Burton, 2011). The issues where some public spaces turned deteriorate and underused (Schroeder \& Anderson, 1983; Bacon, 1976; Jacobs, 1961) are related to the lack of maintenance (Dempsey \& Burton, 2012) may encourage a misperceived consideration of safety (Zelinka and Brennan, 2001). The continued experience over time incites the way in which users perceive the environment, includes perceived maintenance, perceived risk and threat, and perceived personal safety in the park (Sreetheran \& van den Bosch, 2014; Tuan, 2003), and encourage the attachment or detachment to a particular area or place.

Maintenance should consider in the early stage of design and development to provide a last long quality and function of public space. These are to ensure that the public space "fulfill its legitimate roles in a way that is acceptable by users" (Carmona et al, 2008: p. 66), and meet the emotional needs of users' day-to-day lives (Bacon, 1976).

The importance of effective and appropriate maintenance in public spaces often discussed, but the recommendations regarding strategy and practice should not be left behind (Dempsey and Burton, 2011). Therefore, this particular paper addresses the initial findings on perceived maintenance and safety by focusing on the maintenance processes in one of a local municipal council and the current condition of park maintenance in Malaysia from the results of a doctoral study that is still currently ongoing.

\subsection{Literature Review}

The broken window theory by Wilson and Kelling (1982) imposed a different direction on the discussion regarding safety and prevention (Hannan, 2010; Mohit \& Hannan, 2012). They emphasized on physical signs of disorder (e.g., broken properties, vandalism) may encourage crime and reduce the perception of safety amongst the general public. This physical disorder is a visible sign of a place that is unmonitored and uncared for (Wilson \& Kelling, 1982; Dempsey \& Burton, 2012); in the same way, Newman (1972) argues as a sign of lack of care that can lead to physical decay and, ultimately, abandonment. Physical maintenance is important in providing a long-term quality of spaces that come after design and development (Dempsey et al., 2014), which also said as place-keeping. 


\section{Defining landscape maintenance and physical upkeep}

Having said that maintenance plays a significant role in maintaining the quality of public spaces, it is understandable that maintenance, as a part of physical upkeep, is noteworthy in built-up environments, regardless of design and planning phases. This according to Dempsey and Burton (2012), means that public spaces diminished in value as a result of 'damage, disrepair and inadequate maintenance' (Dempsey \& Burton 2012, p.11). Besides, the physical cues arising from maintenance may reduce residents' interest in becoming involved in social activities (Brown et al., 2004) and reduces their interest is utilizing green spaces because of their dissatisfaction with perceived levels of maintenance.

Maintenance is a day-to-day activity taking place to make sure that a condition or state is preserved over an extended period (Dempsey \& Burton, 2012). Carmona et al. (2008) described maintenance as a "process" in which a service takes place, and "product" as a result of a process (e.g., an area cleared from litter) (Dempsey \& Burton, 2012). Maintenance is somehow as much about the "quality of a service provided by the local authority as it is about the quality of the physical environment' (Dempsey, 2008)

Place-keeping is an 'ongoing processes which involve physical and non-physical dimensions' which provides 'physical and non-physical functions' with a combination of characteristics that offers 'the essence of place' (Dempsey \& Burton, 2012, p.13). The nonphysical context involves management by the local authority, that is, their policy in this regard. In short, it can simply understood as a process of preserving a place, and ensure its quality is kept in parallel with the growth of its maturity (e.g., vegetation), as this might as well encourage the growth of a sense of place.

\section{Personal safety-related attributes and physical cues}

Dempsey \& Burton (2012) highlighted different levels of maintenance required depending on the type and character of space, vegetation, users, and context. They also discussed on the effective maintenance- a maintenance that response to changes, and is dependent on the prevailing conditions during any given season, and depending on the maturity of vegetation (ibid, 2012). In short, an effective maintenance occurs when 'the right work is done at the right time' (Carmona et al., 2010).

Perceived safety of the actual physical maintenance is dependent on such factors as:

i) Physical incivilities (e.g., dropping litter, broken pavement, graffiti),

ii) Physical upkeep (e.g., maintenance of soft landscape and hard landscape features such as vegetation, park furniture, playground equipment, rubbish bins)

iii) Signs of negligence (e.g., presence of abandoned features/buildings such as burntout cars, and poor condition of playground equipment and park furniture, and untrimmed vegetation)

Hur and Nasar (2014) emphasized the fact that physical conditions may directly affect residents' perceived safety, despite its potential for incubating incivilities. They divide the conditions into two: physical incivilities and poor upkeep. The incivilities "tend to arise from an action (e.g. dropping litter), while poor upkeep tends to arise from inaction (such as failure to maintain a lawn)" (Hur \& Nasar, 2014, p. 186).

The implication regarding the physical conditions, it is of great importance to mention that 
the actual physical cues may account for perceived appearance, and have direct effects on the perception of personal safety amongst residents (Brown et al., 2004). Hence, according to Dempsey and Burton (2012), people are likely to feel safe in a neat and tidy condition where it shows the visible signs of 'being cared-of.' A study by Hur and Nasar (2014) also found that litter and broken features within the area have a significant impact on perceived safety and influence overall neighborhood satisfaction.

Types of vegetation are one often discussed. Jorgensen et al. (2002) argued that naturalistic landscapes might well be cheaper to maintain, yet promote the impression of a lack of safety. Such environments are more often perceived as being less attractive because of the character of multi-layer structures and dense edges, which visually appear to be impermeable (Jorgensen et al., 2002). It supports the findings of Schroeder and Green (1985) that suggest the general public have a lower preference for dense vegetation.

\subsection{Methodology}

This paper is a pre-evaluation of the research study that only involved reviews on expert interviews and site observation (Yin, 2009). It is to evaluate whether the current processes and procedures documented by MPSJ aligned with their goals and objectives, that could lead to the proper system of landscape maintenance's management and contribute to achieved high-quality recreational landscape (Hussein, 2014; Reeves, 2000).

Experts interviews with eight $(n=8)$ respondents were conducted amongst related personnel that "experience the phenomenon being studied" (Cresswell 1998, p. 118), based on their involvement in landscape development, maintenance and with the community. The aim is to understand the issues about maintenance, to provide options for "a better coordinated and systematic planning for the benefit of the public and environment" (Hussein, 2014). A semi-structured interview was designed to allow a certain degree of freedom and spontaneous discussion.

Table 2. Respondent grouping

\begin{tabular}{llll}
\hline Group & & Code & Number \\
\hline Local authority officers & Landscape department & LA & 2 \\
& Planning department & LP & 1 \\
Site representative & Councilors & CC & 2 \\
& District officials & DO & 3 \\
\hline TOTAL & & 8 \\
\hline
\end{tabular}

Table 3. Three neighborhood parks selected for case studies

\begin{tabular}{lll}
\hline Neighborhood park & Development block (BP) & Code \\
\hline Tasik Seri Serdang & BP7 & NP1 \\
Taman Puchong Perdana & BP5 & NP2 \\
Tasik Wawasan Recreational Park & BP5 & NP3 \\
\hline TOTAL & & 3 \\
\hline
\end{tabular}

Site observations were conducted in three selected neighborhood parks in the urban area 
in Subang Jaya, Selangor. It involves a pre-evaluation on a current site condition, the social activities, and on physical aspect looking on specific maintenance measures that could potentially have implications regarding the perception of safety among users, which later used in formulating a survey questionnaire and participatory workshop.

There is a total of seven planning block or 'blok perancangan' in Malay divided for administrative purposes under the Planning Department. The selection of case studies based on the underlying criteria i.e. the context, of park amenities and features, and maintenance issues.

\subsection{Results and Discussion}

\subsection{Maintenance strategies and documentation in Majlis Perbandaran Subang Jaya (MPSJ)}

The total area under MPSJ is 16,180 hectares (ha), about $32.45 \%$ of the total area of Petaling District. About a quarter (1/4) of total land use consists of green fields, and water bodies (22.53\%, 3,645.49 ha) and 6.66\% (1,077.74 ha) are dedicated to open space and recreation catering for a population of 790,492 .

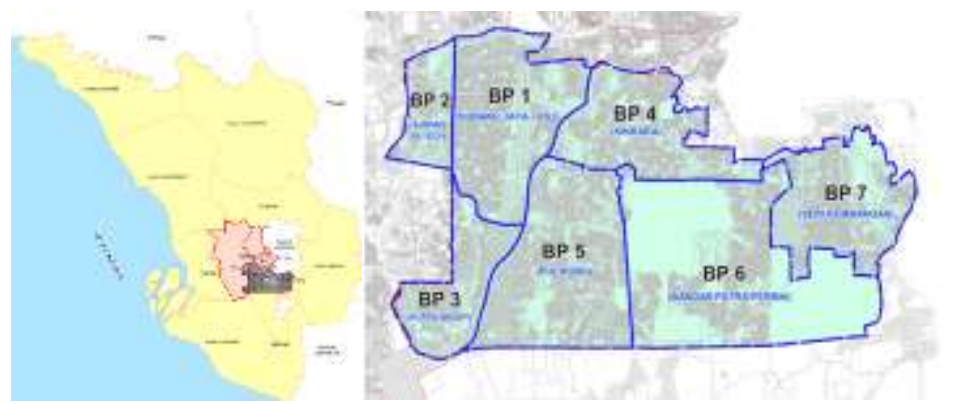

Figure 1: Areas under MPSJ according to planning block (BPs)

(Source: Subang Jaya Structure Plan)

There are only four neighborhood parks under MPSJ supervision that meet the JPBDM (2013) classification- consisting about 0.1 to 2 ha of green areas with a population scales up to twelve thousand $(12,000)$ peoples in an area. Three parks located on the urban fringe, and one in the rural area. There is a lake in neighborhood parks, with different functions and status of presence. The lake itself contribute to the scale of the park and have required a degree of special monitoring, especially for maintenance.

According to the National Landscape Department of Malaysia (JLN), the maintenance of neighborhood park is under the local authority, except in the gated and guarded housing area (JPBD, 2013). According to LA1, most of the housing in Subang Jaya was first built as open public housing. Later, there was considerable demand from the local communities to change their neighborhood into gated and guarded areas, particularly in recent years. Nevertheless, 
the maintenance is still under the auspices of MPSJ. It is different in for a housing area that originally proposed as gated and guarded housing development, where the maintenance and management remain the responsibility of the associated developer.

For landscape maintenance work under MPSJ, there are three departments involved in different aspects of the required work as follows:

a. Landscape department - responsible for waste maintenance in the lake, maintenance of playground equipment, trees, and soft landscape

b. Solid waste management department - waste management in neighborhood parks except for lake and grass trimmings

c. Engineering department - maintenance of soil and other infrastructure including courts, pavements, and walkways

Maintenance works include routine check-ups, recurring work, minor and major repair work, and minor construction work (Sternloff \& Warren, 1977). Maintenance work divided in three practices based on:

a. Periodic maintenance of trees

b. Maintenance of park facilities and play equipment, and

c. Maintenance work regarding complaint resolution

Both periodic tree maintenance, and park facilities and play equipment is a monthly schedule. This particular strategy targets the needs of the users and evolves through time and to keep pace with their demands (Hussein, 2014; Thompson \& Sorvig, 2008). There is an open space inventory report consist of the maintenance work progress and future required works and follow-ups.

Meanwhile, maintenance work for complaint resolution has a particular ISO standard set by the Corporate Department of MPSJ and must comply by all departments- every complaint must be resolved within ten days, and feedback and closure complaint report within three days. As explained by $\mathrm{CC} 2$, there will be a corporate meeting between the managerial board and councilors to discuss any arisen issues, including complaints and associated responses. Complaints are one of the strategies used to tackle the residents' evaluation and responses to the maintenance work, and are one of the means to measure the parks' quality (Thompson \& Sorvig, 2008). It constitutes the users' likes and dislikes regarding the environment, and details the user's perception of how the maintenance "contribute[s] a better co-ordinated and systematic planning for the benefit of the public and built environment" (Hussein, 2014, p.970)

The management of complaints can be considered effective for both the community/residents and the management staff as it can be reached online, via email and the staff website and the progress monitored closely by departments. Residents can submit complaints in four ways: 1) through the complaint counter at MPSJ, 2) the call center, 3) the online Iresponz website- the MPSJ customer website, and 4) the official MPSJ Facebook page.

According to LA1, every complaint logged in the web pages will be directed to the head of maintenance unit email and web page if related to the scope of the department's remit. In ten days, an investigation must be carried out, and a report must be prepared. The report explained the status of the complaint, the immediate works done and any further action requires additional time and an expert work to resolve the issues. 


\subsection{Pre-evaluation from site observation: Landscape maintenance and its effects on the perception of personal safety}

In Malaysia, through the 'safe city program,' the adaptation of Crime Prevention through Environmental Design (known as CPTED) measures as part of its strategies has encouraged a vast amount of study on the adaptability of CPTED approaches in Malaysia's built-up environment (Siti Rasidah \& Aldrin, 2011). In combating personal safety issues in landscape spaces, the CPTED concept underlines two primary prevention measures, those of natural surveillance and access control. In a broader sense, Newman (1972) argued as to the social aspects that contribute to betterment of green spaces, those of milieu and residents' involvement, and which later discussed by Wilson and Kelling (1982) regarding maintenance aspects that contribute to public disorder (Mohit \& Hannan, 2012). The discussion on the initial findings in this paper divided into two: the site context and vegetation.

\section{Site context}

NP1 located in a mixed land uses area consist of vast housing areas, a university (known as Universiti Putra Malaysia, UPM) and a small commercial area. Though there are arguments on mixed land uses increased the actual vulnerability of users in the parks (Mambretti, 2011; Brown et al., 2004; Aldrin et al., 2012) and put anxiety among residents (Lupton, 1999; Saadul Kurzi, 2011), but the variety of activities found in NP1 validated Jacobs (1961) arguments- "the more strangers, the merrier" ( $p .40)$, that claimed the unidentified presence of strangers (Lupton, 1999) on the other hands promotes better surveillance by providing more "eyes on the street".

However, the initial finding on physical attributes shows that there unclear demarcation of neighborhood parks with the surrounding area. A handrail was used on the rear side of NP1 with the secondary road, while in NP2, the park is only one-step separate using a small drain to the primary road. This loophole of the unclear physical barrier explained by Newman (1972) causes insecurity and considerably decrease the possibility of detecting any crime. Unlikely, NP3 is relatively secluded within the residential area, and there is a drain around the park, and fences on the rear side of the park that provide formal surveillance that could curtail entry by strangers (Saadul Kurzi, 2011).

\section{Vegetation}

The characters of vegetation play a major role in promoting behavior and peoples' perception of personal safety in the park (Jorgensen et al., 2002). As the plants grow over time, their maturity and condition require ongoing maintenance, with each type of vegetation accordingly requiring different treatment (Dempsey \& Burton, 2012). One of the main strategies of maintenance consideration by the MPSJ is by minimizing the use of multi-layer planting. Both LAs emphasized the three-layers planting is not encouraged for the cost control not only for development but merely maintenance.

Besides, it was stressed that the periodic plant maintenance and complaint resolutionbased work have been seriously pursued and strictly monitored by The Office Collaboration Productivity System team. During observations at NP1 and NP3, the researchers witnessed a maintenance process that involved grass trimming by awarded contractor staffs, and the 
vegetation as a whole appeared well maintained, regardless of the type of vegetation. However, the conditions in NP2 are slightly different across some of the spaces within the park. It can be seen that there are different conditions on each side of the park. The rear side facing the housing rows appears well cared for, unlike to the other side appear less maintained with a lot of immature planting, and dead trees and bushes, especially at the lake edges. These according to Hussein (2014), damaged or dead trees impose a negative impression on users because they may tarnish the image of particular areas.

\subsection{Conclusion}

By investigating the perception of personal safety on landscape maintenance, it will bring towards a clear understanding of how place conditions (early and long-term) and design of public spaces affects the user's experience of the site. And in turn, it will merely allow predictions of public preferences of green spaces and how it will encourage activities in those places. The comprehensive research is aimed to widen the focus of current concerns for not looking at the design that fits the purposes, but the discussion of how to maintain it for the long-term purposes, probably with low-key maintenance and good aesthetical design. Besides, how the park users perceive the status of park maintenance is also a very important issue to be tackled. The feedbacks contribute to better understanding of the user's preference on individual design and quality of built environment. Nevertheless, the perception studies can also benefit to improve the maintenance strategy in future.

\section{Acknowledgement}

The entirety of this PhD is funded by Majlis Amanah Rakyat (MARA), Malaysia. The first author is supported by MARA for her doctoral studies at the Department of Landscape, University of Sheffield, United Kingdom.

\section{References}

Aldrin, A., Nordin, A. R., Mohd Najib, M. S., \& Siti Rasidah, M. S. (2012). Validating Crime Prevention through Environmental Design Using Structural Equation Model. Procedia - Social and Behavioral Sciences, 36(June 2011), 591-601.

Bacon, E. N. (1976). Design of cities - The University of Sheffield. New York : Penguin Books.

Brown, B., Perkins, D. D., \& Brown, G. (2004). Incivilities, place attachment and crime: Block and individual effects. Journal of Environmental Psychology, 24(3), 359-371.

Carmona, M., Heath, T., Oc, T., \& Tiesdell, S. (2010). Public places - urban spaces : the dimensions of urban design - The University of Sheffield (2nd Editio). Amsterdam ; London : Architectural Press.

Dempsey, N. (2008). Quality of the Built Environment in Urban Neighborhoods. Planning Practice and Research, 23(2), 249-264. 
Dempsey, N., \& Burton, M. (2012). Defining place-keeping: The long-term management of public spaces. Urban Forestry \& Urban Greening, 11(1), 11-20.

Dempsey, N., Smith, H., \& Burton, M. (2014). Place-keeping [electronic resource]: open space management in practice - The University of Sheffield. (N. Dempsey, H. Smith, \& M. Burton, Eds.). New York : Routledge.

Hur, M., \& Nasar, J. L. (2014). Physical upkeep, perceived upkeep, fear of crime and neighborhood satisfaction. Journal of Environmental Psychology, 38, 186-194.

Hussein, M. K. (2014). Users' Perception Towards Selected Recreational Forest Landscape Maintenance In Selangor Darul Ehsan , Malaysia. Pertanika Journal of Social Science and Humanities, 22(October 2013), 969-983.

Jacobs, J. (1961). The Death and Life of Great American Cities. Vintage Books.

Jorgensen, A., Hitchmough, J., \& Calvert, T. (2002). Woodland spaces and edges: their impact on perception of safety and preference. Landscape and Urban Planning, 60(3), 135-150.

JPBD. (2013). Garis Panduan Tanah Lapang dan Kawasan Rekreasi, GP005-A (1st editio). Malaysia: Jabatan Perancangan Bandar dan Desa Semenanjung Malaysia.

Kaplan, R., \& Kaplan, S. (1989). The Experience of Nature. A psychological Perspective. United States of America.

Kashef, M. (2008). Architects and planners approaches to urban form and design in the Toronto region: A comparative analysis. Geoforum, 39(1), 414-437.

Lupton, D. (1999). Dangerous Places and the Unpredictable Stranger: Constructions of Fear of Crime. Australian \& New Zealand Journal of Criminology, 32(1), 1-15.

Mambretti, I. M. (2011). Urban Parks between Safety and Aesthetics.

Mohit, M. A., \& Hannan, M. H. E. (2012). A Study of Crime Potentials in Taman Melati Terrace Housing in Kuala Lumpur: Issues and Challenges. Procedia - Social and Behavioral Sciences, 42(July 2010), 271-283.

Newman, O. (1972). Defensible Space; Crime Prevention Through Urban Design.

Saadul Kurzi, N. (2011). Resident's Perception and Effective Spatial Planning and Design on Property Crime. International Islamic University Malaysia.

Schroeder, H. W., \& Anderson, L. M. (1983). Perception of Personal Safety in Urban Recreation Sites I. Journal of Leisure Research, Second Qua.

Schroeder, H. W., \& Green, T. L. (1985). Public preference for tree density in municipal parks. Journal of Arboriculture, 11(9), 272-277.

Siti Rasidah, M. S., \& Aldrin, A. (2011). CPTED Measures in a Gated Residential Area. Asian Journal of Environment-Behaviour Studies, 2, 33-42.

Sreetheran, M., \& van den Bosch, C. C. K. (2014). A socio-ecological exploration of fear of crime in urban green spaces - A systematic review. Urban Forestry and Urban Greening, 13(1), 1-18.

Thompson, J. W., \& Sorvig, K. (2008). Sustainable landscape construction : a guide to green building outdoors. Island Press.

Tuan, Y. F. (2003). Perceptual and cultural geography: A commentary. Annals of the Association of American 
Kurzi, N.S., \& Schroth, O./ Asian Journal of Quality of Life (AjQoL), 3(13) Sep/ Oct 2018 (p.107-116)

Geographers, 93(4), 878-881.

Wilson, J. Q., \& Kelling, G. L. (1982). Broken Windows. Atlantic (02769077), 249(3), 29.

Yin, R. K. (2009). Case study research : design and methods - The University of Sheffield (Fourth edi). SAGE Publication. 